\title{
Optimizing the Value-at-Risk Measure in European Countries to Better Quantify Market Risk in Banking Industry in Sweden
}

\author{
F. Akhmedov \\ Finance and Credit Department \\ RUDN University
}

\author{
Mhd Shaker Zeitoun \\ Finance and Credit Department \\ RUDN University
}

\begin{abstract}
Market conditions can change rapidly. Empirical evidences from Europe markets show that there can be several years between risk being taken, revenues being generated, and losses flowing through. This is the lesson that the recent financial crisis of 2008 taught us. Stress market conditions in Europe can be extreme in their development and violent in their impact. The financial markets in Europe are always testing new financial products and new banking practices. In this regard, banks in Sweden operate in a challenging environment of competitiveness and complexity. New financial products and new banking practices in Europe markets bring new risk and increase the impact and frequency of existing risks. Therefore, it is highly important to back the risk profile of banks with sophisticated risk models. Risk models pose a problem to any bank. The recommendations set out in this paper to optimize the Value-at-Risk model would help banks in Europe markets to adopt for the complexity of risk, the unpredictability of adverse events, the severity of stress market conditions, and the sophistication of the contemporary banking industry.
\end{abstract}

Keywords-Market Risk, Value-at-Risk (VaR), Stress Market Conditions, Banking Crisis, Asset Portfolio, Risk Model, Banks in Sweden.

\section{INTRODUCTION}

Stress market conditions tend to be extreme in their development and violent in their impact in Europe markets. However, risk models can always be improved. Our paper begins from this insight. The aim is to develop risk models in banks to adopt for the complexity of risk, the unpredictability of adverse events, the severity of stress market conditions, and the sophistication of the banking industry in Europe markets. To this end, this paper considers the case study of banks in Sweden in the development of risk models believing that the case study of these banks represents an overview into some empirical evidences of the banking industry in Europe. The story of banks in Sweden offers many interesting insights into the way that risk must be modeled. The case of banks in Sweden is not just the story of individual banks, but a window into the structural issues of all risk models at banks in Europe markets.

\section{PROBLEM STATEMENT}

Risk models present a problem to any bank. This is because they can always be improved. The emergence of new banking practices and new financial products created new risks. For years, the banking industry has boasted of having the best risk management and risk models of any industry. None of that, however, prevented the recent financial crisis of 2008. It is not altogether unreasonable to say that the history of banking is a history of panics and crises. Most history books cite at least ten distinct bank panics in the 1800s alone, and bank crises in 1907, 1929, and 2008. These crises had significant impacts on the world economy. Stress market conditions, financial crises and market crashes have become a common and widely used part of today's vocabulary. While financial institutions in Europe markets have faced difficulties over the years for a multitude of reasons, the major cause of serious banking problems continues to be directly related to poor risk models. Therefore, we are going to investigate in this paper the following question: how to optimize the Value-at-Risk Model to adequately quantify market risk and to better estimate the worst-case loss in the contemporary banking industry in Europe markets?

\section{OBJECTIVES AND AIM}

The focus of this paper is primarily on risk models to provide banks with the measures they need to a better approach to risk, a better risk management and, ultimately, a better banking industry. The recommendations set out in this paper would result in a change to the Value-at-Risk model in banks. The aim is to optimize the Value-at-Risk model to adequately quantify market risk in Europe markets and to better estimate the worst-case loss over a given horizon and for a given asset portfolio with a stated confidence level.

\section{BACKGROUND AND SIGNIFICANCE}

Risk models can always be improved. From this insight, our paper begins to develop risk models in banks to accommodate the complexity of risk, the unpredictability of adverse events, the severity of stress market conditions, and the sophistication of the contemporary banking industry in Europe markets. This paper considers the case study of banks in Sweden in the optimization of the Value-at-Risk model to better quantify market risks in Europe markets believing that the case study of these banks represents an overview into some empirical evidences of the recent challenges of risk models at banks in Europe markets. The story of banks in Sweden offers many interesting insights into the way that risk must be modeled in the contemporary banking industry in Europe markets. The case of banks in Sweden is not just the story of individual banks, but a window into the structural issues of modelling risk at banks around the world.

\section{AN OVERVIEW OF THE BANKING INDUSTRY IN SWEDEN}

With more than $9.9 \mathrm{mn}$ of population, the Sweden economy in 2017 was nominally US $539.836 \mathrm{mn}$, the $21 \mathrm{st}$ economy in the world in terms of GDP, and one of the world's fastest-growing economies with an average annual GDP growth rate averaged $0.57 \%$ over the past two decades. 
The size of Sweden's banking system is equivalent to multiples of annual gross domestic product (GDP) and dominates the Swedish financial system. It is heavily concentrated with four universal banks holding over 85 percent of all banking system assets.

Sweden's banking sector is sufficiently capitalized and well regulated. Banking in Sweden has been through a long journey. The banking sector reforms undertaken in Sweden from 1991 onwards (since the Swedish banking crisis) were basically aimed at ensuring the safety and soundness of financial institutions and at the same time at making the banking system strong, efficient, functionally diverse and competitive.

\section{OPTIMIZING THE VALUE-AT-RISK MODEL IN EUROPEAN MARKETS}

We believe that risk is often measured in terms of risk probability (the likelihood that a risk will occur) and risk impact (a measure of the consequences if the risk occurs). Markowitz (1952) believes, in his modern portfolio theory, that the traditional approach to risk in finance literature is based on the mean-variance. Therefore, and as market risk is the most familiar of all risks, we believe that the Value-atRisk (VaR) is an accepted methodology for quantifying aggregate risk. In fact, Value-at-Risk has been called the new science of risk management, especially that the most popular and traditional measure of risk is believed to be volatility.

After the introduction of VaR in 1994 by JP Morgan, it became one of the most widely used risk measures in finance. Even Basel Committee considers Value-at-Risk as an acceptable and preferred method for determining the required capital level for a bank trading risk. However, based on our observation, we found that there is no one $\mathrm{VaR}$ number for a single portfolio, because different methodologies used for calculating VaR produce different results. The financial services industry does not have a standard method for Value-at-Risk measures. Broadly speaking, the variance covariance (delta normal), historical simulation, and Monte Carlo simulation are common methods of Value-at-Risk measures in banks. The idea behind the variance-covariance is similar to the idea behind the historical method except that it uses the familiar curve instead of actual data.

By reviewing the literature on risk, we found that a large part of this literature deals with various techniques to measure the risk of banks' asset portfolio (e.g., standard deviation, beta, $\mathrm{VaR}$, etc.). In our opinion, the complexity of risks, the unpredictability of adverse market events, the severity of stress market conditions, and the sophistication of the contemporary banking industry represent new challenges for risk models at banks. Therefore, and as most financial institutions have adopted $\mathrm{VaR}$ as a cornerstone of day-to-day risk measurement, we are going to investigate and optimize the Value-at-Risk Model to adequately estimate the

1 J.G. Maxham III, Service Recovery's Influence on Consumer Satisfaction, Positive Word-ofMouth, and Purchase Intentions, Journal of Business Research, 54 (1) (2001), pp. 11-24

G. Bradley, B. Sparks, Explanations: If, when, and how they aid service recovery, Journal of Services Marketing, 26 (1) (2012), pp. 41-51 magnitude of potential loss in banks over a given horizon and for a given asset portfolio with a stated probability defined as the confidence level. However, as some of the assets of the portfolio can provide banks with a number of remedies to limit their losses in worst-case scenario, we believe that one must take into consideration that a fraction of losses can be recovered as follows:

Expected Loss $(\mathrm{EL})=$ Amount Lost $\times(1-$ Expected Recovery)

By bearing in mind this formula of expected loss (expected recovery), and as $\mathrm{VaR}$ is a risk measure of the expected worst-case loss in normal market conditions, we believe that all risk measures need to consider the expected recovery in their risk calculations. This is because a bad debt, for example a loan, credit line or accounts receivable can be recovered either in whole or in part after it has been written off or classified as a bad debt. Because it generally generates a loss when it is written off; a bad debt recovery usually produces income. For instance, loans can often be rescheduled, customers can be coaxed into repaying a proportion of what they owe in return for forgiveness of the rest, and sometimes banks can seize and then liquidate collateral.

The expected recovery values can vary widely depending on the type of asset and its seniority. It is affected by a number of factors, such as instrument type, corporate issues and macroeconomic conditions. In lending, the recovery rate can be applied to cash extended via loans or credit and recovered by foreclosure or bankruptcy. Knowing how to properly calculate and apply a recovery rate can help banks set rates and terms for future credit transactions. For example, if a recovery rate turns out to be lower than expected, lenders can increase interest rates on a loan or shorten its payout cycle to better manage the added risk.

The type of asset and its seniority within the investment portfolio are among the most important determinants of the recovery rate. The recovery rate is directly proportional to the asset's seniority, which means that an asset that is more senior in the investment portfolio will usually have a higher recovery rate than one that is lower down in the portfolio. However, based on our observation, we found that banks, analysts and investors respond positively to high-expected recovery as it can minimize negative effects. In fact, some studies report that high recovery is more effective in amending investors' dissatisfaction and emotion resulting from failure. 1 Therefore, we believe that it is a better practice to consider the expected recovery in our calculations of Value-at-Risk as follows:

VaR $=($ Z-score $\times$ Standard Deviation $\times$ Portfolio Value $\times$ $\sqrt{ }$ holding days $) \times(1-$ Recovery Rate $)$

Our proposed $\mathrm{VaR}$ measure in this formula represents the maximum loss on the asset portfolio that a bank may sustain over a specified period of time after taking into consideration

B. Choi, The Effects of Perceived Service Recovery Justice on Customer Affection, Loyalty, and Word-of-Mouth, European Journal of Marketing, 48 (1/2) (2014), pp. 108-131 
the expected recovery. This is not because we want to be optimistic in our proposed VaR measure, but because risk models are designed to reflect reality, and we want to be realistic about the expected loss. The expected recovery could be assumed to be zero. There is no problem with that, but it has to be considered in the calculations of $\mathrm{VaR}$.

\section{VALUE-AT-RISK IN BANKS IN SWEDEN}

In Sweden, we believe that banks play an important intermediary role in sustaining development by channeling available funds for productive uses in the economy through borrowing and lending activities. Therefore, we are extremely confident that VaR model is of high importance to quantify the market risk of banks' investment portfolios.

The advantage of the normal distribution in optimizing $\mathrm{VaR}$ is that we automatically know where the worst $5 \%$ and $1 \%$ lie on the curve. Accordingly, our proposed VaR measure can be used to estimate the worst expected loss that an asset portfolio in a bank in Sweden may suffer over a specified period of time and under a specified level of confidence with consideration to expected recovery rate. Therefore, we believe that we can make our calculations of $\mathrm{VaR}$ to measure the maximum expected loss that an asset portfolio in banks in Sweden may sustain at $95 \%$ confidence level, and over a given time horizon. Table 1 illustrates our calculations of VaR in 10 randomly selected commercial banks in Sweden during the recent financial crisis of 2008.

TABle 1. VAR of Asset PoRtFolio In BANKS IN SWEDEN IN 2008 (MILLION SEK)

\begin{tabular}{|c|c|c|c|c|c|c|}
\hline Bank Name & $\begin{array}{l}\text { Asset } \\
\text { Portfo } \\
\text { lio }\end{array}$ & $\begin{array}{c}\text { Confide } \\
\text { nce } \\
\text { Level }\end{array}$ & $\begin{array}{c}Z \\
\text { Sco } \\
\text { re }\end{array}$ & $\begin{array}{l}\text { Std } \\
\text { Dev }\end{array}$ & $\begin{array}{c}\text { Expec } \\
\text { ted } \\
\text { Recov } \\
\text { ery }\end{array}$ & VaR \\
\hline SEB & $\begin{array}{c}705,36 \\
6\end{array}$ & $95 \%$ & $\begin{array}{c}1.64 \\
5\end{array}$ & $\begin{array}{c}1.99 \\
\%\end{array}$ & $10 \%$ & $\begin{array}{c}20,7 \\
81\end{array}$ \\
\hline $\begin{array}{l}\text { Handelsban } \\
\text { ken }\end{array}$ & $\begin{array}{c}790,61 \\
3 \\
\end{array}$ & $95 \%$ & $\begin{array}{c}1.64 \\
5\end{array}$ & $\begin{array}{c}1.99 \\
\%\end{array}$ & $10 \%$ & $\begin{array}{c}23,2 \\
93\end{array}$ \\
\hline Swedbank & $\begin{array}{c}397,51 \\
5\end{array}$ & $95 \%$ & $\begin{array}{c}1.64 \\
5\end{array}$ & $\begin{array}{c}1.99 \\
\%\end{array}$ & $10 \%$ & $\begin{array}{c}11,7 \\
12\end{array}$ \\
\hline $\begin{array}{l}\text { Nordea } \\
\text { Bank }\end{array}$ & $\begin{array}{c}319,77 \\
2\end{array}$ & $95 \%$ & $\begin{array}{c}1.64 \\
5\end{array}$ & $\begin{array}{c}1.99 \\
\%\end{array}$ & $10 \%$ & $\begin{array}{c}9,42 \\
1\end{array}$ \\
\hline $\begin{array}{l}\text { Danske } \\
\text { Bank, filial }\end{array}$ & $\begin{array}{c}290,69 \\
5 \\
\end{array}$ & $95 \%$ & $\begin{array}{c}1.64 \\
5 \\
\end{array}$ & $\begin{array}{c}1.99 \\
\% \\
\end{array}$ & $10 \%$ & $\begin{array}{c}8,56 \\
4 \\
\end{array}$ \\
\hline $\begin{array}{l}\text { DnB NOR } \\
\text { Bank, filial }\end{array}$ & 48,198 & $95 \%$ & $\begin{array}{c}1.64 \\
5\end{array}$ & $\begin{array}{c}1.99 \\
\%\end{array}$ & $10 \%$ & $\begin{array}{c}1,42 \\
0\end{array}$ \\
\hline $\begin{array}{l}\text { Länsförsäkr } \\
\text { ingar Bank }\end{array}$ & 16,390 & $95 \%$ & $\begin{array}{c}1.64 \\
5\end{array}$ & $\begin{array}{c}1.99 \\
\%\end{array}$ & $10 \%$ & 483 \\
\hline $\begin{array}{l}\text { SkandiaBan } \\
\text { ken }\end{array}$ & 44,040 & $95 \%$ & $\begin{array}{c}1.64 \\
5\end{array}$ & $\begin{array}{c}1.99 \\
\%\end{array}$ & $10 \%$ & $\begin{array}{c}1,29 \\
8\end{array}$ \\
\hline $\begin{array}{l}\text { GE Money } \\
\text { Bank }\end{array}$ & 35,408 & $95 \%$ & $\begin{array}{c}1.64 \\
5\end{array}$ & $\begin{array}{c}1.99 \\
\%\end{array}$ & $10 \%$ & $\begin{array}{c}1,04 \\
3\end{array}$ \\
\hline $\begin{array}{l}\text { Dexia Crédit } \\
\text { Local, filial }\end{array}$ & 17,786 & $95 \%$ & $\begin{array}{c}1.64 \\
5\end{array}$ & $\begin{array}{c}1.99 \\
\%\end{array}$ & $10 \%$ & 524 \\
\hline Total & $\begin{array}{c}2,665 \\
783 \\
\end{array}$ & & & & & $\begin{array}{c}78,5 \\
39 \\
\end{array}$ \\
\hline
\end{tabular}

Source: compiled by the author based on Banks' Financial Reports published on

https://view.officeapps.live.com/op/view.aspx?src=https ://www.swedishbankers.se/media/2646/bank-and-financestatistics-2008.xls

Although the measures we used for our calculations of VaR in Table 1 are very simple; nevertheless, they were able to explain what the essence of the VaR model. VaR is essentially the calculation of the standard deviation of an asset portfolio as an indicator of the volatility. A SEK 78,539 $\mathrm{mn} \mathrm{VaR}$ in the banking industry in Sweden means in our opinion a high volatility, and therefore a high probability of making losses. However, based on our observation of banks' financial report in Sweden, we believe that banks in Sweden can withstand shocks arising from possible stress market conditions.

Therefore, by making assumptions that the correlation between assets is excluded, daily fluctuations are independent from yesterday or tomorrow fluctuations (the random walk theory of finance) and that the data have a normal distribution, our proposed $\mathrm{VaR}$ measure for an asset portfolio with lots of assets can be presented as follows:

$$
\begin{aligned}
& \operatorname{VaR}_{\text {Portfolio }}=\sum_{i=1}^{n} \operatorname{VaR}_{(i)}=\{\alpha \times \sigma \times V \times \sqrt{t} \times(1- \\
& \boldsymbol{R})\}
\end{aligned}
$$

where $\mathrm{n}$ is the number of assets in the portfolio, $\alpha$ is $\mathrm{Z}$ score of the confidence interval, $\sigma$ is the standard deviation or the volatility of the asset, $\mathrm{V}$ is the value of the asset, and $\mathrm{R}$ is the expected rate of recovery of the asset, and $\mathrm{t}$ is holding period days.

In our opinion, Value-at-Risk is the best answer to the question of "What is the worst-case scenario?". Speed and simplicity are the main two advantages of our proposed VaR measure. A holding time period and a confidence level are the main parameters of measurement. We believe that risk management at banks can use our proposed $\mathrm{VaR}$ measure to determine what risk management practices should be approached (some of these practices can be found in the next sections) to manage the risks and to hedge the positions of the asset portfolio, to gauge the cash reserves that banks need to set aside to cover potential portfolio losses, or to allocate capital to more efficient channels. Moreover, our proposed VaR measure has proven to be able to adequately reflect the worst-case loss by considering expected recovery in its calculations. This is because:

Some of the assets of the portfolio can provide banks with a number of remedies to limit their losses in worst-case scenario. These assets can be recovered either in whole or in part.

As Value-at-Risk is the expected worst-case loss in normal market conditions. Recovery can happen even in worst-case loss, and especially in normal market conditions.

Recovery rates reached more than $90 \%$ in some cases. However, the expected recovery could be assumed to be zero. There is no problem with that, but that does not mean that the expected recovery should not be considered in the calculations of VaR.

By having considered these arguments, we were successfully able to optimize the VaR Model to adequately quantify market risk in banks by estimating the worst-case loss. Our proposed VaR measure has proven to be able to summarize all the exposures of an asset portfolio into one single meaningful number. Management only needs to 
review the bank's daily VaR number to understand the risk exposure of the asset portfolio, and front office only needs to be notified and warned when positions or losses exceed specified levels to take corrective action, reduce trading volume, suspend trading or take other remedial action. Furthermore, our proposed VaR measure allows banks to implement risk-based limits structures to control and report risks. Risk limits should follow a bank's organizational structure so when risks exceed these limits, risk takers should notify their supervisors. Figure 1 presents an example of how VaR-based limits can be implemented and reported in a bank.

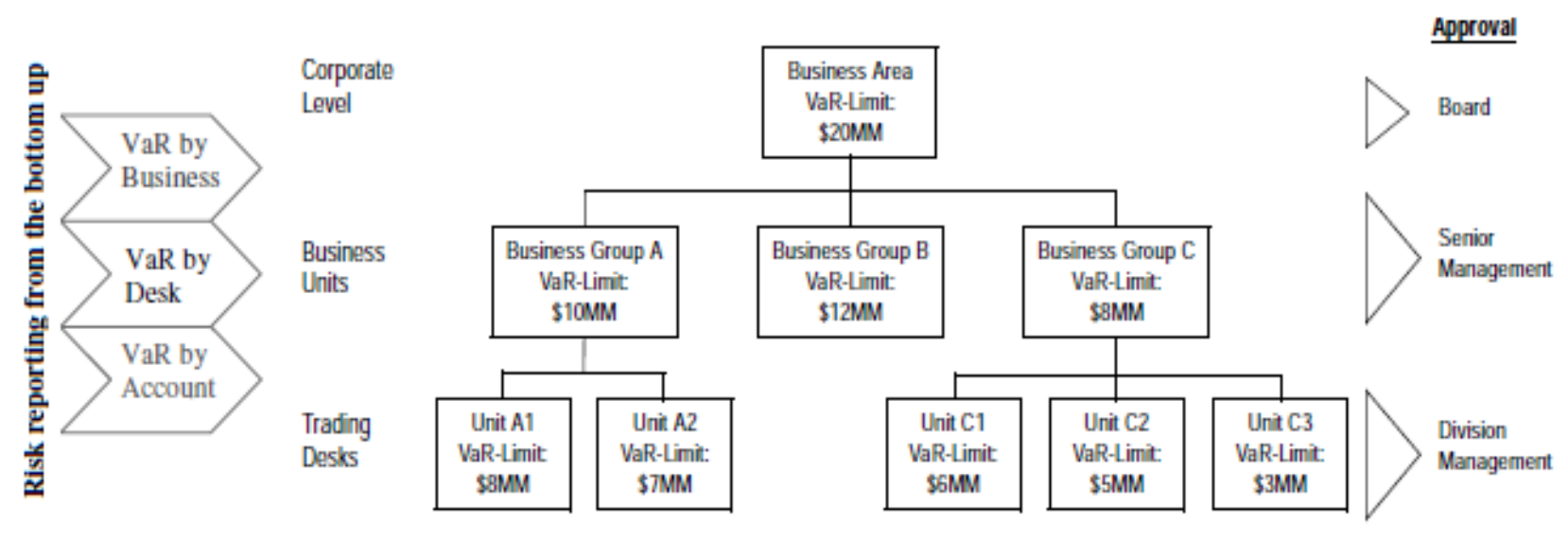

Fig. 1. VaR-based Limits Structure and Reporting in a Bank

Nowadays, we believe that if a bank is not using Valueat-Risk to measure market risk for its trading activities, it will be perceived to be lagging behind the best practice standards in risk management. VaR has become a common language in banks around the world.

\section{CONCLUSIONS:}

1. The emergence of new banking practices and new financial products in Europe markets created new risks and increased the impact and frequency of existing risks. Stress market conditions in Europe markets tend to be extreme in their development and violent in their impact. Therefore, it is highly important to develop risk models in these markets to adequately quantify market risks.

2. Challenges continue in the banking industry in Sweden. While many challenges remain after the banking crisis of the 1990s, the situation of the banking industry in Sweden appears to stabilize in recent years. Banks in Sweden need to pay much attention to the inherent risks at the banking industry. Therefore, the use of quantitative models has been addressed as a very important and sensitive risk management practice to measure risks in banks where theoretical texts cannot help.

3. The Value-at-Risk Model has been successfully optimized and discussed in terms of mathematical expectations to adequately quantify market risk by considering the expected recovery rate in the measure of risk to better summarize all the exposures of an asset portfolio into one single meaningful number that represents the worst- case loss over a given horizon and for a given asset portfolio with a stated confidence level.

4. Some of the assets of the portfolio can provide banks with a number of remedies to limit their losses in worst-case scenario. These assets have proven to be able to recover either in whole or in part as recovery can happen even in worst-case loss, and especially in normal market conditions. Our proposed VaR measure has proven to enable banks to determine what risk management practices should be approached to manage the risks and hedge the positions of an asset portfolio based on risk-based limits structures to control and report risks. Moreover, our proposed VaR measure has been successfully examined on asset portfolios in banks in Sweden to better quantify their market risk.

\section{References}

[1] A.B. Juridik, Bas Nyckeltal, 2010, Stockholm: Nordstedts.

[2] G. Bergendahl and T. Lindblom, "Evaluating the performance of Swedish savings banks according to service efficiency", European Journal of Operational Research, 2008, Vol. 185, pp. 1663-1673.

[3] C. Drury, Management and Cost Accounting 7th Edition, London: Cengage Learning EMEA, 2008.

[4] Finansanalytikernas rekommendationer, Vingåker: Linderoths tryckeri, 2011

[5] T. Hopper, D. Northcott, R. Scapens, Issues in Management Accounting, Essex: Pearson Education Limited, 2007.

[6] C. Helliar, I. Cobb and J Innes, A Longitudinal Case Study of Profitability Reporting in a Bank, British Accounting Review, 2002, Vol. 34, pp. 27-53.

[7] M.M. Hussain, "Management accounting performance measurement of accounting performance measurement systems in Swedish banks", European Business Review, Vol. 17, No. 6, pp. 566-589, 2005. 
[8] M. J. Larson, G. Schnyder, G.Westerhuis, J. Wilson, "Strategic responses to global challenges: The case of European banking", 1973 2000, Business History, Vol. 53, No. 1, pp. 40-62, 2011.

[9] C. Levin, T. Coburn, "Wall Street and the Financial Crisis: Anatomy of a Financial Collapse", Majority and Minority Staff Report, Permanent Subcommittee on Investigations, United States Senate, 2011.

[10] T. Lindblom, C. von Koch, Cross-Border Bank Mergers and Acquisitions in the EU, The Service Industry Journal, Vol. 22, No. 4, pp. 44-72, 2002.

[11] M. Olsson, Fast rotad är den trygghet som byggdes på sparade slantar En analys av sparbankerna värdeskapande på den avreglerade bankmarknaden i Sverige, Bokförlaget BAS, Göteborg, 2009.

[12] K. Soin, T. Scheytt, "Management Accounting in Financial Services", Handbook of Management Accounting Research, 2009.

[13] D. Bai, T. Carpenter, J. Mulvey, "Making a case for robust optimization", Management Science 43, 895-907, 1997.

[14] S. Basak, A. Shapiro, "Value-at-Risk Based Risk Management: Optimal Policies and Asset Prices", Working paper, The Wharton School, 1999.

[15] T.S. Beder, "VAR: Seductive but dangerous", Financial Analysts Journal, Sep/Oct, vol. 12-24, 1995.

[16] D.R. Cariño, T. Kent, D.H. Myers, C. Stacy, M. Sylvanus, A.L. Turner, K. Watanabe, W.T. Ziemba, The Russell-Yasuda Kasai model: An asset/liability model for Japanese insurance company using multistage stochastic programming. Interfaces 24, 291994.

[17] D.R. Cariño, W.T. Ziemba, "Formulation of the Russell-Yasuda Kasa financial planning model", Operations Research 46, 433-449, 1998.

[18] H. Dahl, A. Meeraus, S.A. Zenios. "Some financial optimization models: I risk management”. In Financial Optimization, Zenios (Ed.), Cambridge University Press, Cambridge, 3-36, 1993.

[19] D. Duffie, J. Pan, "An overview of value at risk", Journal of Derivatives 4, 7-49, 1997.

[20] B. Golub, M. Holmer, R. McKendall, L. Pohlman, S.A. Zenios, 1995 , "A stochastic programming model for money management", European Journal of Operational Research 85, 282-296.

[21] R.S. Hiller, J. Eckstein, 1993, "Stochastic dedication: Designing fixed income portfolios using massively parallel benders decomposition", Management Science 39, 1422-1438.

[22] M.R. Holmer, S.A. Zenios, "The productivity of financial intermediation and the technology of financial product management", Operations Research 43, 970-982, 1995.

[23] D. Kalin, R. Zagst, "Portfolio optimization: volatility constraints versus shortfall constraints”, OR Spektrum, 21, 97-122, 1999.

[24] Y.A. Koskosidis, A.M. Duarte, "A scenario-based approach to active asset allocation”, Journal of Portfolio Management 23, 74-85, 1997.

[25] A. Lucas, P. Klaassen, "Extreme returns, downside risk, and optimal asset allocation”, Journal of Portfolio Management 25, 71-79, 1998.

[26] H.M. Markowitz, Portfolio Selection: Efficient Diversification of Investments, John Wiley, New York, 1959.

[27] R. McKay, T.E. Keefer, "VaR is a dangerous technique". Corporate Finance - Searching for systems integration supplement 30, 1996

[28] J.M. Mulvey, R.J. Vanderbei, S.A. Zenios, 1995. "Robust optimization of large-scale systems", Operations Research 43, 264281

[29] M. Pritsker, "Evaluating value at risk methodoligies: Accuracy versus computational time", Journal of Financial Services Research 12, 201242, 1997.

[30] A.V. Puelz, Stochastic convergence model for portfolio selection, Social Science Research Network (SSRN) working paper series (www.ssrn.com), 1999.

[31] K. Simons, "Value at risk - new approaches to risk management", New England Economic Review, Sep/Oct, 3-13, 1996.

[32] F. Stambaugh, , 1996. Risk and value at risk. European Management Journal. 14, 612-621.
[33] S. Uryasev, R.T. Rockafellar, 'Optimization of Conditional Value-atRisk”, Research, 1999.

[34] Report \#99-4, Center for Applied Optimization at the University of Florida.

[35] H. Vladimirou, S.A. Zenios, 1997, "Stochastic linear programs with restricted recourse", European Journal of Operational Research 101, 177-192.

[36] M.R. Young, "A minimax portfolio selection rule with linear programming solution”, Management Science 44, 673-683, 1998. 